\title{
ANALISIS FAKTOR YANG BERHUBUNGAN DENGAN PEMBERIAN ASI EKSKLUSIF PADA IBU PEKERJA
}

\author{
Peny Ariani ${ }^{1}$, Putri Ayu Yessy Ariescha ${ }^{2}$, Juni Vera ${ }^{3}$ \\ Institut Kesehatan Deli Husada Deli Tua \\ Jl. Besar Delitua No 77, Kec. Delitua, Kab. Deli Serdang \\ Sumatera Utara 20355. \\ Email : penyariani@gmail.com
}

DOI : https://doi.org/10.35451/jkk.v2i1.244

\begin{abstract}
Exclusive breastfeeding is increasingly not desirable in working mother. According to Nutrition Status Monitoring in 2016, exclusive breastfeeding is only 54\% and still far from the national target, in North Sumatra alone exclusive breastfeeding is only 46.8\% (KEMENKES, 2016). Exclusive breastfeeding for working mother can help through risk factors that affect exclusively breastfeeding women workers (Sulistiyowati and Siswantara, 2014). The purpose of this study is to study the factors that influence women workers towards exclusive breastfeeding with scientific articles in national journals that are not accredited. The research design that will be used is a case control study with a sample size of 162 cases in working mother and 162 controls in mother who do not work. The study was conducted by analyzing the attitude factors and other social factors towards exclusive breastfeeding assistance that will be done with Chi Square analysis and logistic regression at the real level $a=0.05$. From the results of the study, with bivariate analysis, several factors that influence exclusive breastfeeding for working mothers include; parity $(p=0,000)$, education $(p=0.033)$ and Body Image $(p=0.016)$. From the multivariate results, it was found that Body Image variables that gave the most exclusive breastfeeding to female workers were 27,800838.94 times compared to mothers who had Bad Body Image.
\end{abstract}

\section{Keywords : Exclusive Breastfeeding, Working Mother}

\section{PENDAHULUAN}

Stunting yang merupakan masalah kesehatan nasional menjadi salah satu prioritas pembangunan nasional yang bisa dicegah dengan sasaran jangka menengah nasional melalui perbaikan gizi masyarakat (BAPPENAS,2017). Penyebab Stunting inidiawali oleh Nutrisi pertama kehidupan bayi.

World Health Organization sendiri telah merekomendasikan pemberian ASI eksklusif sampai bayi berusia 6 bulan sebagai pencegahan kejadian gizi buruk dimana berdasarkan data, bahwa 
pemberian ASI Eksklusif berhasil menyelamatkan 1,5 juta bayi/tahun dari gizi buruk di Negara berkembang (WHO, 2017).

Meskipun sudah banyak penelitian tentang manfaat dari ASI, namun cakupan ASI Eksklusif di Indonesia masih rendah yakni hanya sekitar $55,7 \%$ dan masih jauh dari target nasional (Didik Budijanto, drh, 2016).

Hal ini dipengaruhi oleh berbagai faktor antara lain yakni status pekerjaan, dukungan sosial, sikap, pengetahuan dan beberapa factor lain (Inayah and Dian, 2013)

Kebijakan dan peraturan pemerintah yang mendukung ASI Eksklusif ditempat kerja belum maksimal karena memang banyak tempat kerja yang tidak mendukung program ASI Eksklusif, termasuk waktu cuti bersalin, tempat memerah ASI. Sebagian besar perusahaan belum menyediakan tempat menyusui maupun memberikan waktu istirahat untuk memerah ASI atau menyusui bayi. Pekerja hanya diberi waktu istirahat selama setengah jam setelah 4 jam bekerja terusmenerus (Admin, 2015).

Stres akibat pekerjaan merupakan hambatan dalam menyusui eksklusif danmengganggu kesinambungan. Masih banyak pimpinan yang belum mengerti tentang peraturan terkait pemberian ASI Eksklusif pada wanita pekerja, sehingga peraturan perundang undangan belum tersosialisasi dengan baik (Inayah G, 2013).

Edukasi selama kehamilan juga merupakan faktor yang bias mempengaruhi keberhasilan ASI Eksklusif pada wanita pekerja, hal ini didukung oleh pengetahuan dan keterampilan tenaga kesehatan dalam menjelaskan betapa penting dan banyaknya manfaat ASI Eksklusif(Salamonson Y, 2018).

\section{METODE}

Penelitian ini dilakukan di Perkantoran Daerah Delitua, RSU Sembiring Delitua dan Wilayah Kerja Puskesmas Delitua di Kecamatan Delitua Kabupaten Deli Serdang. Penelitian ini dilaksanakan mulai Bulan Januari sampai Bulan September Tahun 2019 dan dilakukan secara deskriptif analitik dengan menggunakan desain case control menggunakan analisis multivariate regresi logistik. Pengambilan sampel dilakukan dengan random sampling menggunakan rumus slovin dengan jumlah sampel 162 orang.

\section{HASIL}

A. Karakteristik Responden

1. Hasil Univariat

Tabel 1. Karakteristik Responden

\begin{tabular}{|c|c|c|c|}
\hline$\overline{\text { No }}$ & Variabel & $\overline{\text { Jumlah }}$ & $\begin{array}{c}\text { Persentase } \\
(\%)\end{array}$ \\
\hline \multirow[t]{3}{*}{1.} & Umur & & \\
\hline & 20- 35 tahun & 98 & 59.4 \\
\hline & $\begin{array}{l}<20 \text { tahun - } \\
>35 \text { tahun }\end{array}$ & 67 & 40.6 \\
\hline \multirow[t]{3}{*}{2.} & Paritas & & \\
\hline & $>1$ & 97 & 58.8 \\
\hline & 1 & 68 & 41.2 \\
\hline \multirow[t]{4}{*}{3.} & Fasilitas & & \\
\hline & Menyusui & & \\
\hline & Ada & 48 & 29.1 \\
\hline & Tidak Ada & 117 & 70.9 \\
\hline \multirow[t]{3}{*}{4.} & Jam Kerja & & \\
\hline & $>8$ jam & 109 & 66.1 \\
\hline & $<8 \mathrm{jam}$ & 56 & 33.9 \\
\hline \multirow[t]{3}{*}{5.} & Lama Cuti & & \\
\hline & $<3$ bulan & 48 & 29.1 \\
\hline & $>3$ bulan & 117 & 70.9 \\
\hline \multirow[t]{4}{*}{6.} & Dukungan & & \\
\hline & Sosial & & \\
\hline & Ada & 130 & 78.8 \\
\hline & Tidak Ada & 35 & 21.2 \\
\hline \multirow[t]{3}{*}{7.} & Body Image & & \\
\hline & Baik & 104 & 63.0 \\
\hline & Tidak baik & 61 & 37.0 \\
\hline
\end{tabular}




\begin{tabular}{llcc}
\hline 8 & Pemberian & & \\
& ASI Eksklusif & & \\
& ASI Eksklusif & 104 & 63.0 \\
Non ASI & 61 & 37.0 \\
Eksklusif & & \\
\hline Total & 165 & 100 \\
\hline
\end{tabular}

\section{Berdasarkan Tabel 1, Data} karakteristik responden yang meliputi umur, paritas, fasilitas menyusui, jam kerja,lama cuti, dukungan sosial, Body Image. meyoritas usia responden adalah umur 20 - 35 tahun yaitu sebanyak 98 orang atau sebanyak 59,4 \%. Mayoritas paritas $>1$ sebanyak 97 orang atau 58,8 $\%$. Mayoritas Tempat bekerja responden yang tidak memiliki fasilitas 117 Orang, atau sebanyak 70,9\%. Mayoritas jam kerja responden $>8$ Jam sebnyak $109(66,1 \%)$. Mayoritas lama cuti responden adalah $>3$ Bulan sebanyak 117 Orang (70,9\%), Mayoritas Responden memiliki dukungan social sebanyak 130 orang $(78,8 \%)$ serta mayoritas memiliki Body Image yang baik yaitu 104 Orang (63\%) dan Mayoritas memberikan ASI Eksklusif sebanyak 104 Orang (63\%).

2. Hasil Multivariat

Tabel 2. Nilai ODDS Ratio pada Variabel Kandidat

\begin{tabular}{llr}
\hline No. & $\begin{array}{c}\text { Variabel X } \\
\text { (variabel } \\
\text { independen) }\end{array}$ & \multicolumn{1}{c}{ Exp (B) } \\
\hline 1. & Pendidikan & 10400275,45 \\
2. & Paritas & $1,286 \mathrm{E}+23$ \\
3. & Body Image & 27800838,94 \\
\hline
\end{tabular}

Berdasarkan Tabel 2, Nilai ODDS Ratio pada Variabel didapatkan bahwa Variabel Pendidikan dengan OR= 10400275,45 maka orang yang memiliki Pendidikan Tinggi lebih beresiko memberika ASI ekskusif sebanyak 10400275,45 kali lipat di bandingkan orang yang memiliki Pendidikan Rendah.
Variabel Paritas dengan OR = $1,286 \mathrm{E}+23$ maka orang yang memiliki Paritas Lebih dari Satu Kali lebih beresiko memberika ASI ekskusif sebanyak $1,286 \mathrm{E}+23$ kali lipat di bandingkan orang yang Paritas nya kurang dari 1 kali

Variabel Body Image dengan OR = 27800838,94 maka orang yang memiliki Body Image yang Baik lebih beresiko memberika ASI ekskusif sebanyak 27800838,94 kali lipat di bandingkan orang yang memiliki Body Image yang Tidak Baik. Maka urutan nilai Exp (B) dari yang terbesar terhadap Status ASI Faktor Terbesar Pertama: Paritas Faktor Terbesar Pertama: Body Image Faktor Terbesar Pertama: Pendidikan

\section{PEMBAHASAN}

Rentang umur yang dimiliki ibu melahirkan tidak mempengaruhi dirinya atau tindakannya dalam memberikan asi eksklusif kepada Bayi. Hasil penelitian ini berbeda dengan penelitian yang dilakukan oleh Sariyanti (2015) yang menunjukkan hasil penelitian bahwa ada hubungan umur ibu dengan pemberian ASI Eksklusif. Menurut Wawan dan Dewi (2010) dalam Sariyanti (2015) sebagian besar ibu yang memberikan ASI Eksklusif umur 20-30 tahun dimana pada umur tersebut adalah masa reproduksi sehat sehingga ibu mampu beradaptasi dengan baik terkait proses yang dialaminya sejak hamil, bersalin, nifas dan menyusui.

Perilaku seseorang baik positif maupun negatif akan dipengaruhi oleh umur dan umur termasuk dalam faktor prediposisi, dimana semakin matang umur seseorang maka secara ideal semakin positif perilakunya dalam memberikan ASI Eksklusif (Depkes RI, 2005). Namun pada Wanita di Kantor Camat Kecamatan Sunggal Kabupaten Deli Serdang, Wanita dalam pemberian asi eksklusif tidak 
dipengaruhi oleh umur. Hal ini dapat dipengaruhi bahwa pengetahuan Ibu yang bekerja pada daerah penelitian tentang pemberian asi Eksklusif kepada bayi masih kurang. Hal ini sejalan dengan penelitian yang dilakukan oleh Sulistyowati (2014) juga menunjukkan hasil penelitian bahwa tidak terdapat hubungan antara usia (umur) ibu dengan Pemberian Asi Ekslusif.

Paritas dapat mempengaruhi Ibu dalam memberikan asi eksklusif kepada Bayi. Hasil penelitian ini berbeda dengan penelitian yang dilakukan oleh Sariyanti (2015) dimana tidak ada hubungan yang signifikan antara jumlah paritas ibu dengan pemberian ASI Eksklusif.

Fasilitas menyusui di tempat bekerja tidak mempengaruhi dirinya atau tindakannya dalam memberikan asi eksklusif kepada Bayi. Namun hasil penelitian ini berbeda dengan hasil penelitian yang dilakukan oleh Nurdiana (2016) dimana Ada hubungan ketersediaan fasilitas penunjang ASI eksklusif dengan pemberian ASI di wilayah kerja Puskesmas Bonorowo, Kabupaten Kebumen.

Jam kerja yang dimiliki ibu yang bekerja tidak mempengaruhi dirinya untuk memberikan asi eksklusif kepada Bayi dan lama cuti yang dimiliki ibu setelah melahirkan mempengaruhi dirinya atau tindakannya dalam memberikan asi eksklusif kepada Bayi. Hal ini sejalan dengan hasil penelitian Fransisca (2014) yang menunjukan hasil penelitian bahwa lama cuti bersalin berpengaruh terhadap pemberian asi meskipun tidak secara statistic.

Dukungan sosial yang dimiliki ibu melahirkan tidak mempengaruhi dirinya atau tindakannya dalam memberikan asi eksklusif kepada Bayi. Namun hasil penelitian ini berbeda dengan penelitian lainnya, penelitian yang dilakukan Fahriani dkk (2014) yang menunjukkan bahwa faktor yang terbukti mempengaruhi pemberian ASI eksklusif adalah faktor psikis ibu (keyakinan ibu terhadap produksi ASI), dukungan keluarga, pengetahuan ibu yang benar tentang ASI eksklusif, dan konseling ASI dari petugas kesehatan.

Body Image yang baik terkait dengan pemberian ASI Eksklusif dan dapat menurunkan tekanan psikologis pascasalin untuk semua wanita, tetapi tingkat pendidikan adalah prediktor paling signifikan untuk pemeliharaan dalam regresi multivariat termasuk Body Image.Body Image dimediasi, tetapi tidak memoderasi hubungan antara berat badan dan pemberian ASI EKsklusif. Body Image secara keseluruhan lebih rendah pada wanita gemuk, tetapi semua wanita memiliki kepuasan Body Image yang rendah di sekitar persalinan, berkurang lebih lanjut pada 6-8 minggu (Swanson, Keely dan Denison, 2017).

Studi Hauff \& Demerath(2012) pada ibu primipara dengan status gizi overweight dan obese menunjukkanbahwa ibu overweight dan obese memiliki median durasi pemberian ASI yanglebih singkat serta beresiko tinggi menghentikan pemberian ASI pada satu tahunpertama setelah melahirkan. Rendahnya kepercayaan diri serta kepuasan terhadapbentuk tubuh setelah melahirkan memiliki hubungan negatif dengan durasipemberian ASI.

Perbedaan kepercayaan diri terhadap tubuh sendiri sebelum hamil dansetelah melahirkan dapat merubah niat seorang ibu yang semula inginmemberikan ASI eksklusif menjadi ingin memberikan susu formula saja (Hauff \&Demerath 2012). Body Image saat hamil, diet selama kehamilan, Body Imagesetelah melahirkan, serta perubahan BB memiliki hubungan bermakna dengandurasi pemberian ASI 
eksklusif pada 2, 6, 12, dan 26 minggu usia bayi.Perubahan berat badan (berat badan setelah melahirkan lebih besar daripadasebelum hamil) akan meningkatkan kekhawatiran seorang wanita terhadap bentuktubuhnya. Wanita dengan Body Image negatif setelah melahirkan cenderungmemiliki durasi pemberian ASI eksklusif yang lebih pendek karena praktik dietsetelah melahirkan, rasa malu ketika harus menyusui di tempat umum dan kekhawatiran tentang dampak menyusui terhadap bentuk tubuhnya (Brown et al.2014).

\section{KESIMPULAN}

Body Image yang paling berhubungan dengan pemberian ASI EKsklusif pada wanita pekerja.

Implementasi dari hasil penelitian ini selanjutnya peneliti akan melaksanakan Pengabdian Kepada Masyarakat tentang Kelompok Sehat Reproduksi Wanita Berbasis Grup Whatssapp di Pesantren Al Raudhatul Hasanah Medan, serta membangun komunikasi jejaring kepada kelompok Sehat Reproduksi karena mayoritas peserta kelompok adalah wanita pekerja. Tahapan selanjutnya adalah akan melaksanakan penelitian terkait ASI Eksklusif pada wanita pekerja dengan variable yang masih dirasa perlu untuk diteliti, karena Body Image merupakan variable yang paling berpengaruh, sehingga bisa diperluas cakupan Body Image pada wanita pekerja melalui penelitian kualitatif sehingga factor yang berhubungan dapat lebih detil ditemukan.

\section{DAFTAR PUSTAKA}

Admin.Undang-undang dan Peraturan Tentang Menyusui dan Bekerja [Internet].Menyusui. Info. 2015. Av ailabel from:http://menyusui.info/re gulasi/undang-undang-dan- peraturan-tentang-menyusui-danbekerja.

BAPPENAS. Rencana Pembangunan Jangka Menengah Nasional 2015-2019. 2017;313. Availabel from: http://w ww.social. protection.org/gimi/gess/ RessourcePDF.action?ressource.ress ourceId $=5007$.

Brown A, Rance J, Warren L. 2014. Body Image Concerns During Pregnancy areAssociated with a Shorter Breastfeeding. J Midwifery. 31 (1): 80-89.Datamikro K, Statistik BP. Indonesia-Survei Angkatan Kerja Nasional 2013 Triwulan 1. 2016;172.

Didik Budijantodrh, Hardhana B, Yudianto M, drg. Titi Soenardi Ms, Dalam Negeri K, Pusat Statistik B, et al. Data and Information Indonesia Health Profile 2016. Yoeyoen Aryantin Indrayani SDs; B BSigit; Sinin[Internet].

2016;168. Available from:http://ww w.depkes.go.id/resources/download /pusdatin/lain-lain/Data dan Informasi Kesehatan Profil Kesehatan Indonesia 2016 - smaller size -web.pdf.

Fahriani dkk. Faktor yang Memengaruhi Pemberian ASI Eksklusif pada Bayi Cukup Bulan yang Dilakukan Inisiasi Menyusu Dini (IMD). 2014. Sari Pediatri.

Inayah G, Dian A. Determinan Perilaku Pemberian Air Susu Ibu Eksklusif Pada Ibu Pekerja. Kesmas. 2013;7(7):298-303.

Kamariyah N. Kondisi Psikologi Mempengaruhi Produksi ASI Ibu Menyusui di Bps Aski Pakis Sido Kumpul Surabaya. J Heal Sci. 2017;7(1).

KEMENKES. Profil Kesehatan Indonesia Tahun

2016. 
https://www.depkes.go.id/resources/do wnload/pusdatin/infodatin/infodatinasi.pdf. 2016.

Sulistiyowati T, Siswantara P. Perilaku Ibu Bekerja Dalam Memberikan ASI Eksklusif di Kelurahan Japanan Wilayah Kerja Puskesmas KemlagiMojokerta. ] Promkes [Internet]. 2014;2(1):89-100. Availabel from:http://journal.unair.ac.id/filerP DF/jupromkesd6de2ea109full. pdf.

Sariyanti, Rentang umur yang dimiliki ibu melahirkan tidak mempengaruhi dirinya atau tindakannya dalam memberikan asi eksklusif kepada Bayi, tahun 2015.

Swanson, Keely dan Denison.Does Body Image influence the relationship between body weight and breastfeeding maintenance in new mothers?.Volume22, Issue3, September 2017. Pages 557-576. 2017.

Wawan dan Dewi, hubungan umur ibu dengan pemberian ASI Eksklusif, tahun 2010.

WHO. Breastfeeding [Internet]. WHO. 201 7. Available from:http://www.who.i nt/maternal_child_adolescent/topics /newborn/nutrition/breastfeeding/e n. 